\title{
Hubungan Riwayat Berat Badan Lahir Rendah (BBLR) dengan Perkembangan Motorik Kasar Anak Usia 12-24 Bulan
}

\author{
Lindra Anggorowati ${ }^{1}$, Lukman Fauzi $^{2}$, Saidatur Rochmah ${ }^{1}$ \\ ${ }^{1}$ Program Studi Administrasi Kesehatan, Fakultas Sains dan Teknologi, Universitas IVET, \\ Indonesia, ${ }^{2}$ Program Studi Kesehatan Masyarakat, Fakultas Ilmu Keolahragaan, Universitas \\ Negeri Semarang, Indonesia
}

\section{Info Articles}

Sejarah Artikel:

Disubmit 15 Agustus 2021

Direvisi 10 September 2021

Disetujui 12 Oktober 2021

\section{Keywords:}

LBW, Gross Motor, Child

Development, Children 12-24

Months

\begin{abstract}
Abstrak
Proporsi BBLR di Kabupaten Kendal mengalami tren kenaikan sejak tahun 2016 yakni $4,16 \%$ pada $2016 ; 4,2 \%$ pada 2017 ; dan $4,4 \%$ pada 2018 . Riwayat BBLR diduga berkaitan dengan tingkat aktifitas fisik yang lebih rendah di kemudian hari yang diukur dengan perkembangan motorik kasar pada anak usia dini. Penelitian ini bertujuan ini mengetahui hubungan BBLR dengan masalah perkembangan motorik kasar anak usia 12-24 bulan. Sampel dalam penelitian ini dibedakan menjadi 2 kelompok, yaitu kelompok kasus dan kontrol dengan perbandingan 1:3. Analisis data dilakukan secara bivariabel, dengan uji Chi-square dan multivariabel, dengan uji regresi logistic. Hasil menunjukan bahwa variabel berat badan lahir dan variabel status ibu bekerja berhubungan dengan perkembangan motorik kasar dengan nilai p berturut-turut 0,001 (OR: 5,66, CI 95\%: 2,028-15,791) dan 0,007 (OR: 4,12, CI 95\%: 1,472-11,527). Anak yang memiliki riwayat berat badan lahir rendah berisiko 5,66 kali lebih besar mengalami masalah perkembangan motorik kasar dibandingkan dengan anak yang memiliki riwayat berat badan lahir normal, setelah mempertimbangkan status ibu bekerja.

Kata kunci : BBLR, Motorik Kasar, Perkembangan Anak, Anak 12-24 Bulan
\end{abstract}

\section{Abstract}

The proportion of $L B W$ in Kendal Regency has experienced an increasing trend $4.16 \%$ in 2016; $4.2 \%$ in 2017; and 4.4\% in 2018. A history of low birth weight is thought to be associated with lower levels of physical activity in later life as measured by gross motor development in early childhood. This study aims to determine the relationship between low birth weight and gross motor development problems in children aged 12-24 months. The sample in this study was divided into 2 groups, the case group and the control group with 1:3 as the ratio. Data analysis was performed bivariately, with Chisquare test and multivariable, with logistic regression test. The results showed that the variable birth weight and working mother status variables were associated with gross motor development with pvalues of 0.001 (OR: 5.66, 95\% CI: 2.028-15.791) and 0.007 (OR: 4.12, CI 95\%: 1,472-11,527). Children who have a history of low birth weight have a 5.66 times greater risk of experiencing gross motor development problems compared to children who have a history of normal birth weight, after considering the status of working mothers.

Keywords: LBW, Gross Motor, Child Development, Children 12-24 Months

\begin{tabular}{lc}
\hline Alamat Korespondensi: Lindra Anggorowati, Prodi Administrasi & p-ISSN 2721-8503 \\
Kesehatan, Fakultas Saintek, Universitas Ivet, J1. Pawiyatan Luhur IV & e-ISSN 2775-9997 \\
No. 17 Semarang 50233, Telp: (024) 8316105-8316118, Fax. (024) &
\end{tabular}

8316105. E-mail: lindraanggorowati@gmail.com 


\section{PENDAHULUAN}

Anak usia 12-24 bulan merupakan bagian dari masa periode emas yang mengalami perkembangan otak dengan pesat. Pendidikan dan pengasuhan yang diterima anak sejak lahir hingga usia enam tahun memiliki efek signifikan terhadap pertumbuhan, perkembangan, dan potensi pembelajarannya di masa mendatang (UNICEF, 2020). Masa usia dini merupakan tahapan penting dalam meningkatkan kondisi kesehatan sepanjang hidupnya. Berbagai penelitian telah menunjukan banyaknya masalah kesehatan yang dihadapi berawal dari kondisi kesehatan pada masa usia dini. Pemerintah berbagai negara berupaya menyusun dan menerapkan kebijakan dengan memperkuat investasi pada anak usia dini (Irwin et al., 2007).

Tantangan pengembangan anak usia dini adalah tingkat partisipasi pendidikan anak usia dini jauh di bawah target nasional 77\% RPJMN 2015-2019, Provinsi Jawa Tengah hanya mampu mencapai $49,7 \%$. Kesenjangan ini tentunya mencerminkan bahwa kabupaten/kota yang berada di wilayah Jawa Tengah pun rata-ratanya belum mampu mencapai target yang ditentukan secara nasional (UNICEF, 2020). Kabupaten Kendal sebagai salah satu wilayah yang berada di Jawa Tengah sepatutnya berupaya dalam mencapai target yang ditetapkan nasional (Dinkes Kab. Kendal, 2018).

Kebijakan lain yang perlu disoroti adalah upaya penurunan kasus anak dengan berat badan lahir rendah (BBLR). Penurunan 30\% kasus BBLR merupakan salah satu target WHO dalam perbaikan gizi ibu, bayi dan anak pada tahun 2025 (World Health Organization, 2002). Kondisi berat badan lahir rendah di Indonesia menjadi penyebab utama kematian neonatal pada Tahun 2019. Dari 20.244 kasus kematian pada masa neonatus, terdapat 35,3\% disebabkan oleh kondisi berat badan lahir rendah (Kemenkes RI, 2020). Proporsi BBLR di Kabupaten Kendal mengalami tren kenaikan sejak tahun 2016 yakni 4,16\% pada 2016 ; 4,2\% pada 2017; dan 4,4\% pada 2018 (Dinkes Kab. Kendal, 2016, 2017, 2018). Meskipun bayi BBLR tanpa komplikasi dapat mengejar ketertinggalan berat badan seiring dengan bertambahnya usia, namun terdapat konsekuensi yang harus dihadapi seperti risiko kematian dan kesakitan pada masa neonatal, perkembangan kognitif yang terhambat, dan risiko penyakit kronik dimasa mendatang (Kemenkes RI, 2020; World Health Organization, 2002).

Beberapa riset menunjukan bahwa riwayat BBLR berkaitan dengan tingkat aktifitas fisik yang lebih rendah dikemudian hari. Aktifitas fisik dapat ditunjukan dengan keterampilan motorik dan perkembangan kognitif pada anak-anak prasekolah (Aoyama et al., 2017; Zeng et al., 2017). Bahkan anak dengan riwayat BBLR memiliki kemampuan yang lebih rendah dibandingkan dengan yang berat lahir normal (Goisis et al., 2017). Anak dengan riwayat masalah perkembangan motorik pada usia dini merupakan prediktor awal aktifitas fisik yang dapat ditunjukan dengan tingkat partisipasi olah raga pada masa remaja yang rendah (Aoyama et al., 2017).

Keterampilan motorik yang baik menjadi aspek penting bagi perkembangan fisik, sosial, psikologis anak yang terkadang kurang dipahami. Usia prasekolah merupakan penentu pengembangan keterampilan motorik dan sebagai jendela waktu yang paling strategik dalam upaya peningkatan keterampilan motorik di masa mendatang (Hestbaek et al., 2017). Pemantauan perkembangan anak seharusnya dapat dilakukan melalui pelaksanaan program SDIDTK (Stimulasi, Deteksi dan Intervensi Dini Tumbuh Kembang) (Dinkes Kab. Kendal, 2016, 2017, 2018), sayangnya capaian pelaksanaan program ini tidak terlaporkan dalam Profil Kesehatan Dinas Kesehatan tahun 2016, 2017 dan 2018. Hal ini patut diantisipasi karena jika program tersebut tidak berjalan maka skrining masalah perkembangan pada anak usia dini tidak dapat ditanggulangi sedini mungkin.

Berdasarkan latar belakang diatas peneliti bermaksud mengetahui sejauh mana riwayat BBLR terhadap perkembangan motorik kasar anak usia 12-24 bulan dengan mempertimbangkan tempat tinggal di desa dan di kota. Penelitian ini penting dilakukan mengingat begitu banyak dugaan determinan perkembangan motorik kasar yang perlu dibuktikan dengan mempertimbangkan berbagai aspek. Dalam penelitian ini, peneliti memiliki hipotesis bahwa ada hubungan riwayat BBLR dengan perkembangan motorik kasar pada anak usia 12-24 tahun. 


\section{METODE}

Penelitian ini merupakan penelitian observasional analitik, dengan rancangan penelitian unmatched case control. Metode kasus kontrol digunakan untuk menilai peran variabel yang Populasi penelitian ini adalah semua anak berusia 12-24 bulan yang orang tuanya berdomisili di wilayah Kabupaten Kendal. Instrumen yang digunakan adalah kuesioner terstruktur untuk mengetahui riwayat berat lahir anak, pendidikan ibu, pekerjaan ibu, dan tempat tinggal. Adapun Denver II digunakan untuk mengukur perkembangan motorik kasar anak sesuai umurnya pada anak yang mempunyai tanda-tanda keterlambatan perkembangan motorik kasar maupun anak sehat. Denver II bukan merupakan tes IQ dan bukan merupakan peramal kemampuan intelektual anak di masa mendatang. Tes ini tidak dibuat untuk menghasilkan diagnosis, namun lebih ke arah untuk membandingkan kemampuan perkembangan seorang anak dengan kemampuan anak lain yang seumur (Frankenburg \& Doods, 2012).

Sampel dalam penelitian ini dibedakan menjadi 2 kelompok, yaitu kelompok kasus dan kontrol. Kasus didefinisikan sebagai anak berusia 12-24 bulan yang mengalami gangguan perkembangan motorik kasar berdasarkan hasil pemeriksaan dengan instrumen Denver II. Kontrol didefinisikan sebagai anak berusia 12-24 bulan yang tidak mengalami gangguan perkembangan motorik kasar berdasarkan hasil pemeriksaan dengan instrumen Denver II. Kasus dan kontrol dipilih secara acak berdasarkan penelusuran data sekunder dan pengambilan sampel dilakukan dengan multistage random sampling. Penentuan besar sampel dihitung berdasarkan rumus ukuran besar sampel untuk menguji hipotesis 2 proporsi tidak berpasangan, dengan tingkat kepercayaan 95\% $(1,96)$ dan kekuatan penelitian $80 \%(0,842)$. Perbandingan kasus dan kontrol adalah 1:3 yang telah memenuhi kriteria inklusi dan eksklusi. Berdasarkan perbandingan tersebut didapatkan 24 sampel kasus dan 72 sampel kontrol.

Analisis data dilakukan analisis secara deskriptif dan analitik terhadap semua variabel penelitian. Analisis univariabel dilakukan untuk mendapatkan distribusi frekuensi dari data hasil pengukuran pada karakteristik responden dan mendapatkan gambaran variabel independen dan dependen. Analisis bivariabel menggunakan uji Chi-square dengan tingkat kemaknaan 95\%, yang disertai dengan penghitungan nilai odds ratio (OR) 95\% CI untuk menilai besarnya pengaruh determinan terhadap kejadian perkembangan motorik kasar anak. Adapun analisis multivariabel yang digunakan untuk menganalisis hubungan beberapa variabel independen secara bersama-sama dengan kejadian gangguan perkembangan anak, menggunakan uji statistik regresi logistik. Analisis regresi logistik juga digunakan untuk mengetahui variabel independen yang paling dominan mempengaruhi variabel dependen serta mengetahui keberadaan interaksi variabel. Analisis bivariabel dan multivariabel tersebut dilakukan dengan menggunakan software SPSS 22.

\section{HASIL DAN PEMBAHASAN}

Responden penelitian ini sejumlah 96 anak usia 12-24 bulan yang terdiri dari 24 kasus dan 72 kontrol. Hasil uji statistik ditunjukan dalam analisis bivariabel yang tersaji dalam Tabel 1. Uji statistik menunjukan bahwa nilai $\mathrm{p}$ variabel riwayat berat lahir anak dengan perkembangan motorik kasar sebesar 0.001 CI 95\% sebesar 2.058-15.127 dengan OR 5.58 maka dapat disimpulkan bahwa ada hubungan antara riwayat berat lahir rendahdengan perkembangan motorik kasar anak. 
Tabel 1. Karakteristik responden penelitian berdasarkan berat badan lahir, jenis kelamin, status ibu bekerja, pendidikan ibu, dan tempat tinggal.

\begin{tabular}{|c|c|c|c|c|c|c|c|c|}
\hline \multirow{2}{*}{ Variabel } & \multicolumn{2}{|c|}{ Kasus } & \multicolumn{2}{|c|}{ Kontrol } & \multicolumn{2}{|c|}{ Jumlah } & \multirow{2}{*}{$P$-value } & \multirow{2}{*}{ OR (CI 95\%) } \\
\hline & $\mathrm{N}$ & $\%$ & $\mathrm{n}$ & $\%$ & $\mathrm{n}$ & $\%$ & & \\
\hline \multicolumn{9}{|l|}{ Berat Badan Lahir } \\
\hline - Rendah & 16 & 66,7 & 19 & 26,4 & 35 & 36,5 & 0,001 & $5,58(2,058-15,127)$ \\
\hline - Normal & 8 & 33,3 & 53 & 73,6 & 61 & 63,5 & & \\
\hline \multicolumn{9}{|l|}{ Jenis Kelamin } \\
\hline - Perempuan & 15 & 62,5 & 36 & 50 & 51 & 53,1 & 0,408 & $1,67(0,647-4,296)$ \\
\hline - Laki-laki & 9 & 37,5 & 36 & 50 & 45 & 46,9 & & \\
\hline \multicolumn{9}{|l|}{ Pendidikan } \\
\hline - Rendah & 17 & 70,8 & 28 & 38,9 & 45 & 46,9 & 0,013 & $3,81(1,404-10,370)$ \\
\hline - Tinggi & 7 & 29,2 & 44 & 61,1 & 51 & 53,1 & & \\
\hline \multicolumn{9}{|l|}{ Status Ibu Bekerja } \\
\hline - Bekerja & 14 & 58,3 & 19 & 26,4 & 33 & 34,4 & 0,009 & $3,9(1,486-10,261)$ \\
\hline - Tidak Bekerja & 10 & 41,7 & 53 & 73,6 & 63 & 65,6 & & \\
\hline \multicolumn{9}{|l|}{ Tempat Tinggal } \\
\hline - Pedesaan & 14 & 58,3 & 33 & 45,8 & 47 & 49,0 & 0,409 & $1,65(0,650-4,213)$ \\
\hline - Perkotaan & 10 & 41,7 & 39 & 54,2 & 49 & 51,0 & & \\
\hline Jumlah & 24 & 100 & 72 & 100 & 96 & 100 & & \\
\hline
\end{tabular}

Variabel lain yang menjadi variabel interest, meliputi jenis kelaminm pendidikan ibu, status ibu bekerja, dan tempat tinggal. Variabel pendidikan dan status ibu bekerja menunjukan berhubungan dengan pekembangan motorik kasar anak dengan nilai p $0.013(<0.05)$ dan $0.009(<0.05)$. Sedangkan variabel jenis kelamin dan tempat tinggal menunjukan tidak berhubungan dengan perkembangan motorik kasar anak dengan nilai p $0.408 \quad(>0.05)$ dan $0.409 \quad(>0.05)$. Selanjutnya, analisis multivariabel dilakukan pada variabel yang memiliki nilai $\mathrm{p}<0.25$ meliputi variabel berat lahir, pendidikan ibu dan status ibu bekerja. Hasil analisis multivariable dari beberapa variabel tersebut dengan perkembangan motorik kasar anak disajikan dalam tabel 2 .

Tabel 2. Hasil Analisis multivariabel antara berat badan lahir dan perkembangan motorik anak

\begin{tabular}{llcccc}
\hline \multirow{2}{*}{ Variabel } & B & Wald & P value & OR (CI 95\%) \\
\cline { 3 - 6 } & & & & & \\
\hline Step 1 & Berat Badan Lahir & 1,726 & 10,721 & 0,001 & $5,62(1,99-15,790)$ \\
\hline & Pendidikan & 0,664 & 1,033 & 0,309 & $1,94(0,540-6,989)$ \\
\hline \multirow{2}{*}{ Step 2 } & Status Ibu Bekerja & 1,015 & 2,474 & 0,116 & $2,76(0,779-9,781)$ \\
\hline & Berat Badan Lahir & 1,733 & 10,957 & 0,001 & $5,66(2,028-15,791)$ \\
\hline & Status Ibu Bekerja & 1,416 & 7,269 & 0,007 & $4,12(1,472-11,527)$ \\
\hline
\end{tabular}

Setelah mempertimbangkan variabel lain, variabel berat badan lahir dan variabel status ibu bekerja tetap berhubungan dengan perkembangan motorik kasar dengan nilai $p$ berturut-turut 0,001 dan 0,007. Anak yang memiliki riwayat berat badan lahir rendah berisiko 5,66 kali lebih besar mengalami masalah perkembangan motorik kasar dibandingkan dengan anak yang memiliki riwayat berat badan lahir normal, setelah mempertimbangkan status ibu bekerja. Hasil tersebut selaras dengan penelitian di Ceara Brasil yang menyatakan bahwa berat bayi lahir rendah berhubungan dengan kemampuan komunikasi, kemampuan motorik dan kemampuan memecahkan masalah. Hal tersebut diduga karena bayi dengan berat lahir rendah dipengaruhi oleh faktor selama kehamilan, dimana sang ibu tidak mendapat suplementasi asam folat yang baik. Asam folat sangat penting dalam 
pembentukan tabung saraf dan diperlukan untuk produksi precursor RNA dan DNA. Kadar folat yang rendah dapat mengakibatkan kelainan proliferasi sel, termasuk pada neuron dan ketidakstabilan DNA dan kerusakan kromosom. Hal ini menunjukan kurangnya suplementasi asam folat selama kehamilan akan berkaitan dengan defisit motorik pada anak dan rendahnya kemampuan pemecahan masalah. Dalam hal perawatan neonatus pada bayi dengan berat lahir rendah adalah membutuhkan resusitasi, antibiotik untuk infeksi, atau rawat inap yang diperpanjang setelah lahir memiliki skor perkembangan yang lebih rendah di domain tertentu. Selanjutnya, apabila tidak memulai menyusui dalam satu jam pertama setelah kelahiran berkaitan dengan skor perkembangan motorik kasar dan sosial yang lebih rendah. Perkembangan motorik bayi yang tertunda dapat memprediksi tingkat aktivitas fisik yang lebih rendah pada anak-anak. Hal tersebut menunjukan bahwa kondisi kehamilan dan perawatan neonatus berhubungan dengan hasil perkembangan anak di kemudian hari (Rocha et al., 2021).

Disisi lain, hasil analisis yang menunjukan bahwa variabel status ibu bekerja menjadi aspek yang perlu diperhatikan mengingat berhubungan pula dengan perkembangan motorik kasar $(<0.05)$. Intervensi yang tepat untuk mencegah kurangnya aktivitas fisik diperlukan kepada bayi dengan perkembangan motorik yang lebih lambat (Aoyama et al., 2017). Penelitian di Calabar tentang ibu bekerja (mother employment) menunjukkan bahwa ada kondisi terputusnya antara tuntutan pekerjaan ibu dan pola perilaku anak dan perkembangan keterampilan verbal dan sosial anak sebagai akibat dari tidak adanya pengasuhan orang tua. Kurangnya interaksi berkualitas dikarenakan jumlah bulan yang diberikan kepada ibu sebagai cuti hamil perlu ditambah dari 4 bulan menjadi 9 bulan. Penambahan bulan cuti diharapkan dapat menambah waktu berkualitas dengan anak dalam proses tanggung jawab pengasuhan (Ering, 2014). Hal ini selaras pula dengan penelitian Handoyo (2020) dengan data IFLS 5 (Indonesia Family Life Survey 5) in 2014 bahwa pemerintah perlu memberikan pemotongan waktu kerja bagi ibu yang memiliki anak balita khususnya bayi baru lahir, agar dapat memberikan waktu bagi anak untuk perbaikan kesehatan anak di masa mendatang (Handoyo et al., 2020). Pemerintah dan pimpinan tempat bekerja perlu mempertimbangkan kebijakan yang tepat dalam cuti bekerja terutama kepada ibu dengan bayi yang baru lahir dan yang memiliki anak balita, agar dapat memiliki waktu yang berkualitas untuk menstimulasi pertumbuhan dan pekembangan anak.

\section{SIMPULAN}

Berdasarkan analisis hasil dan pembahasan, didapatkan kesimpulan bahwa riwayat anak dengan berat badan lahir rendah dan status ibu bekerja berhubungan dengn masalah perkembangan motorik anak usia 12-24 bulan di Kabupaten Kendal. Dinas Kesehatan Kabupaten Kendal perlu menentukan kebijakan dalam upaya meningkatkan pelayanan kesehatan ibu dan anak dengan menerapkan deteksi dini dalam pemeriksaan kesehatan ibu selama hamil, pemantauan kesehatan anak secara berkala dengan melibatkan petugas pelayanan kesehatan yang terlatih meliputi dokter, bidan, perawat, dan kader kesehatan. Melalui kebijakan yang tepat, masalah kesehatan ibu yang dapat menyebabkan BBLR dan masalah perkembangan motorik anak dapat dideteksi lebih dini sehingga penanggulangnya dapat dilakukan lebih awal.

\section{DAFTAR PUSTAKA}

Aoyama, T., Tanaka, S., Tanaka, M., Okuda, M., Inoue, S., \& Tanaka, C. (2017). Birth weight and infant motor development in relation to physical activity in childhood. Japan Journal of Human Growth and Development Research, 2017(74), 9-18. https://doi.org/10.5332/hatsuhatsu.2017.74_9

Dinkes Kab. Kendal. (2016). Profil Kesehatan Kabupaten Kendal Tahun 2016. https://dinkes.kendalkab.go.id/docs/dokumen_perencanaan/profil_kesehatan_kabupaten_ke ndal_tahun_2016.pdf 
Dinkes Kab. Kendal. (2017). Profil Kesehatan Kabupaten Kendal Tahun 2017. https://dinkes.kendalkab.go.id/docs/dokumen_perencanaan/profil_kesehatan_kabupaten_ke ndal_tahun_2017.pdf

Dinkes Kab. Kendal. (2018). Profil Kesehatan Kabupaten Kendal Tahun 2018. In Dinas Kesehatan Kabupaten Kendal. https://dinkes.kendalkab.go.id/docs/dokumen_perencanaan/profil_kesehatan_2018.pdf

Ering, S. O. (2014). Mothers Employment Demands and Child Development : An Empirical Analysis of Working Mothers in Calabar Municipality University of Calabar Felix Udo Akpan, $\mathrm{PhD}$ University of Calabar. American International Journal of Contemporary Research, 4(4), 184-191.

Frankenburg, W. K., \& Doods, J. B. (2012). Manual Tes Denver II (Second Edi). Subbagian Pediatri Sosial/ Tumbuh Kemban- INSKA-FK-UGM/RSUP Dr. Sardjito.

Goisis, A., Özcan, B., \& Myrskylä, M. (2017). Decline in the negative association between low birth weight and cognitive ability. Proceedings of the National Academy of Sciences of the United States of America, 114(1), 84-88. https://doi.org/10.1073/pnas.1605544114

Handoyo, R. D., Erlando, A., \& Septiyanto, I. (2020). Dampak Faktor Eksternal Terhadap Pertumbuhan Ekonomi Indonesia. EcceS (Economics, Social, and Development Studies), 7(1), 1. https://doi.org/10.24252/ecc.v7i1.13382

Hestbaek, L., Andersen, S. T., Skovgaard, T., Olesen, L. G., Elmose, M., Bleses, D., Andersen, S. C., \& Lauridsen, H. H. (2017). Influence of motor skills training on children's development evaluated in the Motor skills in PreSchool (MiPS) study-DK: study protocol for a randomized controlled trial, nested in a cohort study. Trials, 18(1), 400. https://doi.org/10.1186/s13063-0172143-9

Irwin, L. G., Siddiqi, A., \& Hertzman, C. (2007). Early Child Development : A Powerful Equalizer Early Child Development : A Powerful Equalizer.

Kemenkes RI. (2020). Profil Kesehatan Indonesia Tahun 2019 (Vol. 42, Issue 4).

Rocha, H. A. L., Sudfeld, C. R., Leite, Á. J. M., Machado, M. M. T., Rocha, S. G. M. O., Campos, J. S., Silva, A. C. e., \& Correia, L. L. (2021). Maternal and neonatal factors associated with child development in Ceará, Brazil: a population-based study. BMC Pediatrics, 21(1), 1-9. https://doi.org/10.1186/s12887-021-02623-1

UNICEF. (2020). Situasi Anak di Indonesia - Tren, Peluang, dan Tantangan dalam Memenuhi Hakhak Anak. Unicef, 8-38.

World Health Organization. (2002). Low birth weight. Journal of the American Medical Association, 287(2), 270. https://doi.org/10.1001/jama.287.2.270

Zeng, N., Ayyub, M., Sun, H., Wen, X., Xiang, P., \& Gao, Z. (2017). Effects of Physical Activity on Motor Skills and Cognitive Development in Early Childhood: A Ssytemic Review. BioMed Research International, 2017, 1-13. http://eds.b.ebscohost.com.lopes.idm.oclc.org/eds/pdfviewer/pdfviewer?vid=2\&sid=8a87340 b-dc13-429f-990c-b6f01ec2262d\%40sessionmgr120 